\title{
ОРГАНІЗАЦІЯ СИСТЕМИ ПЕРВИННОЇ МЕДИКО-САНІТАРНОЇ ДОПОМОГИ НА ЗАСАДАХ СІМЕЙНОЇ МЕДИЦИНИ ТА РОЛЬ МЕДИЧНОЇ СЕСТРИ
}

\author{
О. Г. Яковлева \\ Комунальне некомериійне підприємство \\ "Севєродонеџький центр первинної медико-санітарної допомоги»
}

У статті висвітлено основні підходи та вимоги до переходу надання первинної медико-санітарної допомоги населенню, основні функції та роль медичної сестри загальної практики - сімейної медицини в задоволенні потреб пацієнтів та необхідності формування її професійно-педагогічної компетентності як основи етико-деонтологічної та професійної діяльності.

\section{ORGANISATION OF THE SYSTEM OF PRIMARY MEDICAL AND SANITARY AID ON THE BASIS OF THE FAMILY MEDICINE AND ROLE OF A NURSE}

\author{
O. G. Yakovleva
}

\section{Municipal non-profit enterprise "Severodonetsk Center of Primary Health Care"}

\begin{abstract}
The article outlines the basic approaches and requirements to the primary medical and sanitary aid to the population, basic functions and roles of nurses of general practice and family medicine in satisfaction of patients' needs and the necessity of professional and pedagogical competence formation as the base of ethical, deontological and professional activity.
\end{abstract}

Вступ. Світова спільнота відводить первинній медико-санітарній допомозі (ПМСД) важливе місце в процесі забезпечення здоров'я населення і провідну роль у ході реформування системи охорони здоров'я. ПМСД $\epsilon$ першою сходинкою в контакті між окремою сім'єю, особою, громадою і національною системою охорони здоров'я, яка максимально наближає медичну допомогу до місць проживання/роботи і створює перший елемент неперервного процесу охорони здоров'я. Це ґрунтується на шести актуальних принципах ПМСД, визначених фахівцями ВОО3:

- самозабезпеченість;

- участь населення;

- міжсекторальне співробітництво;

- інтеграція служб охорони здоров'я;

- посилення уваги до груп високого ризику;

- використання раціональних технологій [4].

За оцінками G. Wienke та W. Boerma, первинна медико-санітарна допомога є професійною відповіддю пацієнту, який вперше контактує з системою охорони здоров'я. Відповідно до висновків фахівців, сильні системи охорони здоров'я, основані на первинній

(C) О. Г. Яковлєва, 2019 медичній допомозі, потребують менших витрат, ніж більш «відкриті» системи, а результати, досягнуті ними - кращі $[10,11]$.

Саме рівень організації роботи первинної ланки багато в чому визначає такі ключові моменти, як якість, доступність і своєчасність медичної допомоги, розвиток профілактичного напряму, раціональність використання ресурсів галузі [1, 3].

Головними завданнями галузі охорони здоров'я $\epsilon$ збереження і зміцнення здоров'я громадян, забезпечення їх доступною і якісною медичною допомогою з метою подовження тривалості активного життя, поліпшення його якості $[4,5]$.

ВООЗ сформулювало чотири складові, які забезпечують якість медичної допомоги: кваліфікація спеціалістів, оптимальне використання ресурсів, вираховування ризику для пацієнтів та їх задоволеність [6].

Надання якісної медичної допомоги має розпочинатися з лікувальних закладів за місцем проживання. Саме від взаємодії з сімейним лікарем та сімейною медичною сестрою залежить поведінка пацієнта, прихильність його до профілактичних і лікувальних заходів та можливість контролю його стану здоров'я. 
Первинна медико-санітарна допомога розглядається як один із провідних інструментів досягнення здоров'я для всіх в Європейському регіоні. Лише розвиток первинної медико-санітарної допомоги на засадах загальної практики/сімейної медицини (ЗП/СМ) дасть змогу поліпшити демографічну ситуацію, досягти справедливого розподілу і раціонального використання бюджетних коштів. Первинна медикосанітарна допомога є основною і найважливішою ланкою в організації охорони здоров'я населення. Реформа охорони здоров'я в нашій країні передбачає поступовий перехід до організації первинної медичної допомоги за принципом лікаря загальної практики. Але однією з головних умов реформи $\epsilon$ збереження всіх лікувально-профілактичних установ охорони здоров'я, зі зміною їхніх функцій, методів роботи, удосконаленням їхньої діяльності, заміною дільничної служби на лікаря загальної практики. Одним із важливих моментів $є$ формування команди медичних сестер ЗП/СМ [7, 9].

Глобальне завдання сучасного медсестринства розвивати та удосконалювати первинну ланку медичного обслуговування, зробити її доступною для всіх. Медичні сестри - головні спеціалісти та найчисельніша категорія медичних працівників, які забезпечують населення усіх країн первинною медичною допомогою [2]. Накопичений досвід показав, що дані соціологічних досліджень $є$ інформативним показником для оцінки ефективності діяльності медичних закладів та розробки рекомендацій щодо поліпшення діяльності як закладів охорони здоров'я, так і системи охорони здоров'я в цілому. Тому актуальним $є$ аналіз результатів моніторингу рівня задоволеності громадян якістю надання первинної медико-санітарної допомоги.

Мета дослідження - вивчити та проаналізувати місце та роль медичної сестри у системі надання первинної медико-санітарної допомоги населенню.

Основна частина. Для досягнення мети дослідження було розроблено анкету, яка містить 24 питання, 3 приводу якості надання первинної медико-санітарної допомоги та необхідності реформування системи охорони здоров'я.

Анкету заповнювали громадяни самостійно, вона була анонімною. Результати виражали у відсотках. Всього було опитано 80 респондентів, віком від 18 років. 3 них жінок - $56 \%$, чоловіків - $44 \%$.

На питання про те, чим керуються пацієнти при виборі сімейного лікаря, респонденти відзначили наступне: 26,3 \% - власним бажанням, 15,8 \% - по- радою рідних, друзів та знайомих та 5,3 \% - з інших причин. 3 них при виборі сімейної медичної сестри,15 \% опитаних керуються порадою рідних та друзів, 35 \% опитаних - власним бажанням та 45 \% - за місцем проживання.

Найчастіше метою звернення до сімейного лікаря серед пацієнтів $\epsilon$ лікування гострих захворювань (70\% респондентів), профілактичний огляд (20\% респондентів), лікування хронічного захворювання (5 \% респондентів) та з інших причин (5\% респондентів).

Факторами, що створюють перешкоду для звернення до сімейного лікаря або пройти обстеження, визначено такі: великі черги (60\%), недовіра до лікаря (25\%), висока вартість послуг (10\%); все влаштовує (5\% опитаних). На питання «Як часто Ви контактуєте з сімейною медичною сестрою?» відповіді розподілились таким чином: 38,1 \% - коли є потреба в допомозі в питаннях щодо профілактики захворювань, 33,3 \% щоразу як відвідую сімейного лікаря та 28,6 \% - коли $\epsilon$ потреба в лікуванні. Позитивний контакт із сімейною медичною сестрою склався у $10 \%$ опитаних, довірливий - у $15 \%$ та нейтральний - у $75 \%$.

Задоволеними ставленням медичної сестри виявилося $40 \%$ респондентів, частково задоволеними $15 \%$, незадоволеними - 20 \% та не визначилися - $25 \%$ респондентів. На частоту невдоволення не впливали вік та стать опитаних.

На рівень задоволеності пацієнтів наданням медичної допомоги впливають такі чинники: обсяг наданих діагностичних та лікувальних процедур (23,8 \%), пояснення лікаря та медичної сестри (19\%), ввічливість медичних працівників (14,3\%), рівень знань та вмінь лікарів та медичних сестер (38,1 \%) та інші чинники (4,3 \%). Задоволеними рекомендаціями та порадами, які були надані щодо лікування, виявилося $45 \%$ опитаних, не визначилися - 30 \%, байдуже - $5 \%$ та незадоволені - 20 \%. Відсутньою $є$ залежність задоволеності пацієнтів роботою сімейного лікаря.

На питання «В якому напрямку потрібно вдосконалювати роботу медичних працівників?» відповіді розподілилися таким чином: якість проведення діагностичних та лікувальних процедур (28,6 \%), підвищувати рівень знань та вмінь медичних працівників (42,9\%), працювати над ввічливістю та тактом медичних працівників (14,3 \%), покращувати матеріально-технічну базу (14,3 \%). На питання «Чи давали Вам рекомендації щодо збереження та покращення стану здоров'я?» були отримані такі відповіді: ні, не давали (60 \%), 
так, проводив сімейний лікар (30 \%), так, проводила медична сестра (5 \%), так, проводять регулярно (5 \%).

Профілактику захворювань та роботу над збереженням здоров'я пацієнтів проводять медичні працівники на неналежному рівні. 3 отриманих результатів опитування було з'ясовано, що 85,7 \% респондентів вважають, що потрібно проводити реформування охорони здоров'я та 14,3 - не можуть дати відповідь.

На питання «В якому напрямку необхідно проводити реформу в медицині?» більшість респондентів зазначає, що в профілактичному (33,3 \%), в економічному (19\%), страхову медицину (19\%), первинну медичну допомогу (19\%) та сімейну медицину (9,6 \%). Це свідчить про те, що необхідно удосконалювати профілактичний напрямок системи охорони здоров'я України, що дозволить підвищити якість та подовжити життя населення.

Більш ніж 50-річний досвід існування сімейної медицини в світі засвідчив медико-соціальну та економічну ефективність цієї моделі системи охорони здоров'я. Реформування системи ПмСД на засадах загальної лікарської практики/сімейної медицини в Україні забезпечить поліпшення стану здоров'я на-

\section{СПИСОК ЛІТЕРАТУРИ}

1. Апанасенко Г. Л. Охрана здоровья здоровых: постановка проблемы в Украине и России / Г. Л. Апанасенко // Український медичний часопис. - 2010. - № 4 (72). С. 122-124.

2. Аналіз проблем первинної медико-санітарної допомоги через призму незалежного скринінгового анкетування населення Закарпатської області / І. В. Чопей [та ін.] // Сімейна медицина. - 2012. - № 1 (спеціальний випуск). - С. 15-21.

3. Бібик І. Г. Удосконалення надання психіатричної допомоги на рівні первинної медико-санітарної допомоги / І. Г. Бібик // Східноєвропейський журнал громадського здоров'я : матеріали Міжнар. наук.-практ. конф., присвяченої Всесвітньому дню здоров'я : тези доповідей. - 2013. - № 1 (21). - С. 93-94.

4. Корнійчук О. П. Удосконалення економічного механізму розвитку первинної медико-санітарної допомоги в Україні / О. П. Корнійчук // Український медичний часопис. - 2012. - № 3. - С. 128-133.

5. Охорона здоров'я України: проблеми і напрямки розвитку / В. М. Лехан, Г. О. Слабкий, М. В. Шевченко [та ін.] // Вісник соціальної гігієни та організації охорони здоров'я України. - 2011. - № 4. - С. 5-18. селення на основі удосконалення системи медичної допомоги, наближення її до кожної сім'ї, підвищення рівня доступності, якості та ефективності при раціональному використанні ресурсів галузі.

Оцінка якості та ефективності медичної допомоги повинна безперервно функціонувати в кожному лікувально-профілактичному закладі. Тільки через підвищення якості надання медичної допомоги можна досягти високого рівня задоволеності пацієнта.

Якість медичної допомоги повинна стати основним правилом у роботі медичних працівників.

Основне завдання сучасного медсестринства - розвивати та удосконалювати первинну ланку медичного обслуговування, зробити їі доступною для всіх. Медичні сестри є однією з важливих ланок в охороні здоров'я, здатні забезпечити на всіх рівнях профілактику захворювань, реабілітацію та медсестринський догляд.

Висновки. Проведене соціологічне дослідження свідчить про те, що галузь охорони здоров'я України потребує подальшого реформування та постійного удосконалення роботи первинної ланки надання медичної допомоги.

6. Основные документы Всемирной Организации Здравоохранения. - Женева, 2009. - 261 с.

7. Ткаченко В. І. Історія розвитку та сучасний стан первинної медичної допомоги за кордоном та в Україні, нормативно-правова база впровадження сімейної медицини в Україні / В. І. Ткаченко // Сімейна медицина. 2015. - № 3. - С. 12-17.

8. Шарлович 3. П. Залежність успіху в одужанні пацієнта від діяльності медичної сестри загальної практики сімейної медицини / 3. П. Шарлович // Вища освіта в медсестринстві: проблеми і перспективи : науково-практична конференція з міжнародною участю 17-18 жовтня 2013 р., Житомир. - Житомир : ТОВ 505, 2013. - С. 309-312.

9. Шніцер Р. І. Вивчення задоволеності населення якістю медичного обслуговування (на прикладі Свалявського району Закарпатської області) / Р. І. Шніцер, Р. Ю. Рогач, Л. В. Погоріляк // Науковий вісник Ужгородського університету. - 2012. - № 1 (43). - С. 168-170.

10. Scottish Public Health Observatory. Scot PHO Tobacco Profiles 2013.NHS Board \& CHP Overview. - Edinburgh: ISD Scotland, 2013.

11. Wienke G. Coordination andintegration into Europ eanprimary care / G. Wienke, W. Boerma // Thechiefdoctor. - 2006. - No. 12. 